\title{
Inclusive Education Training Model Based On Need Assessment And Andragogy For Elementary School Teachers
}

\author{
Irdamurni $i^{\mathrm{a}}$ \\ ${ }^{a}$ Department of Special Education, Universitas Negeri Padang, Indonesia \\ Corresponding e-mail: Irdamurni241161@gmail.com
}

\begin{abstract}
The problem that occurs in Padang Elementary School is the lack of competence in implementing inclusive education from the teachers. This study aims to develop a training model based on need assessment and andragogy in order to improve the competence of teachers in implementing inclusive education in Elementary School, as well as to evaluate the effectiveness and practicalities of training model. The type of research is Research and Development (R \& D). The development procedure uses the ten step. The products of this research are: (a) the training model of inclusive education based on the need assessment and andragogy that consists of three books, namely book 1 about the training implementation technique of inclusive education, book 2 contains about the program and plan of inclusive educationtraining, and book 3 is about the training material, (b) the significant improvement on the competence of teachers about inclusive education after the implementation of training model, with an average value of $67.5 \%$ before training, and up to $80.6 \%$ after training, (c) practical and effective training model to improve the competence of teachers in implementing inclusive education in Elementary School.
\end{abstract}

Keywords: Training model of inclusive education, need assessment, andragogy

\section{INTRODUCTION}

This research was motivated by the low competence of teachers on implementing inclusive education in Padang Elementary Schools (Irdamurniresearch, 2013). The result of observation had shown that $90 \%$ of regular teachers in inclusion classroom do not conduct assessment for children with special need, $75 \%$ of regular teachers in the inclusion classroom do not develop curriculum that accommodate the children with special need, and $67 \%$ of teachers cannot use the method and media as well as the assessments on children with special need in inclusionclassroom. Schools need to have teachersfor special educationthat implements inclusive education according to the criteria in Permendiknas no. 70 year 2009, Permendiknas no. 70 year 2009, states that in implementing inclusive education, school stakeholders must pay attention to 8 (eight) components, which are: (1) the students in inclusive education, including the identification and assessment of children with special need, (2) the curriculum of inclusive education, (3) the teachers in inclusive education, (4) learning activities, (5) assessment and certification, (6) management of schools, (7) rewards and sanctions, and (8) community empowerment.

According to O'Neil, (1995), Sapon-Shevin, (2007), Dyah (2008), and Budiyanto (2005), inclusive educationis the education service system that requires that all children with special need to study at nearby schools, in regular classes with the friends of their age. Therefore, school restructurisation is needed, so that it can become a community that supports the fulfillment of specific needs of all children, with sufficient learning resources and supports from all parties, namely the students, teachers, parents, and the community. Through inclusive education, children with special need are educated with other normal children in order to optimize its potential (Freiberg, 1995).Then, Berit H. Johnsen and Meriam D. Skorten (2003: 288) state that the principles that are accommodated to inclusive school have caused the great demands on teachers for both regular and special education.It demandsthe shift from tradition of "teaching the same material to all students in the classroom", to become teaching each child according to their individual needsin classroom setting. Furthermore, Scott (1995) mentions that "the success of the inclusive education depends, to a large extent, on the willingness and the ability of teachers to the make accommodations for individuals with special needs". Scott emphasizes that the success of inclusive education depends on the extend of teachers willingness and ability to accommodate the needs of children with special needs. 
The implementation of inclusive education is in accordance with Indonesian Republic Constitution no. 14 year 2005 and Government Regulation no. 19 year 2005, the teachers are required to have competence. This competence include: (1) pedagogical competence, (2) professional competence, (3) social competence, and (4) personal competence. Depdiknas, (2006:57), and Rothwell (1996) state that competence is the ability to behave, to think and to act consistently as an embodiment of knowledge, attitude, and skill possessed by learners. The competency is importantfor educators, because with a good competence, teachers will be able to develop learners to achieve educational goalsin Constitution no. 20 year 2003 about the national education system Article 3 that reads: national education aims to develop students' potentials to become a man of faith and devoted to Allah, the Almighty God, good attitude, healthy, knowledgeable, skill, creative, independent, and become democratic and accountable citizens.

Therefore, competence is a set of knowledge and skills that must be owned by a person in performing the duties. Those knowledge and skills can be acquired in the pre-position education and/or training. Sikula in Sumantri (2000:2) defines training as: "short-term educational process that uses systematic and organized methods and procedures. Furthermore, Ernesto A. Franco (1991) and Hadari Nawawi (1997:107) say that training is an act to improve a person's skills and knowledge in performing particular tasks. The trainees will learn knowledge and skill that are practical for a particular purpose". Training can imply more specific meaning, which is associated with the job/task performed by someone. While the term of practicalmeans that the trained respondents can be applied immediately so it must be practical (Fandi Tjiptono, 1996).

Trainees on the implementation of this model has an average age of 35-50 years, according to Lovell in Anisah Basleman (2011:19-20).In this period, people try to develop themselves in their profession and also in the surrounding neighborhood. That age requires different methods and procedures with the learning of school-age children. Thus, the application of learning model based on need assessment meansthat it is in accordance with the materials needed by teachers or learners on the implementation of inclusive education, it is obtained from the tests given to participants. It is relevant to the opinion of Dittman (2004) and De Marco (1978), need assessmentis the reaction from informal method previously used. The main feature of this method is the narrative description thatis arranged in sequence of activities in accommodation with the needs of trainees. John
Mc Neil (1985) defines need assessment as: the process that learners defines their educational needs and decides their priorities. This definition is in line with the opinion of Mc Neil, Seels and Glasglow (1990), they describe the definition of need assessment as the means to gather information about the differences and to use that information in making decisions about priorities.

Meanwhile, according to Knowles (Sudjana, 2005:62), andragogy is the science and arts of helping adults learn. It is different with pedagogy, because this term can be defined as the science and arts of teaching children. Dugan Laird (Hendayat S., 2005: 135) says that andragogy learns how adults learn. Laird is convinced that adults learn in a way that is significantly different from the ways of the child in acquiring new behavior. According to Lunandi (1987), the most important thing in adult education is: What is learned by the student, instead of what is taught by the teachers. It means that the learning result is assessed from what is obtained by the adults from aneducationalmeeting/training, not from what is taught by the teacher or trainer or speaker in that meeting.

The concept of training is designed for participants conditions that are generally over 35 years old. In accordance to the opinions of Knowles, Laird, Brundage, in Saleh Marzuki (2012:166), andragogy is the art and science of teaching adults. The science of teaching alone is not enough and must be combined with art. Therefore, educating is a combination of science and art in helping others, both children and adults, in learning. By definition,andragogy is the art and science of teaching adults. However in its application, in andragogy there are approaches, strategies, methods, techniques and tactics. The emphasis in the application of andragogy learning lies in the age factor of participants that is considered to have the most influence in the training. So, a model of training that includes learning needs of adults is needed.

Training model that is developed has role in improving the competence of teachers in implementing inclusive education in Elementary Schools. The products of this research have produced three books, namely book 1 about the training implementation technique of inclusive education, book 2 contains about the program and plan of inclusive educationtraining, and book 3 is about the training material.The model that has been designed bythe researcher is relevant with Employees Training Center Depdiknas(2003) mentions that the products to be produced from a design model of training have to include the following: (1) a description of micro training programs that covers the type of training, description 
of purposes and programs qualification, instructors and its qualifications, the place and time of implementation, the structure of the curriculum and outline of lesson plans (GBRP), (2) requirements (specification) on each unit of training activities, including the sequencing of learning objectives, determining thesetting and technique or method for training, and also the required exam requirements, (3) the training implementation plan.

The purpose of this research to develop a model of inclusive education training for Elementary School teachers, and also to evaluate the effectiveness and practicalities of inclusive education training model that is being developed.

\section{RESEARCH METHODS}

The type of this research is research and development. The development procedures that is used follow the steps proposed by Borg and Gall (1983:775), Dick, W., \& Carey, L. (1996) and Sugiono (2011:407). Those steps have been revised by theresearcher to accomodate the needs of research, which are: (1) Research and information collectiing, depart from the potential of teachers and the problems regarding the implementation of inclusive education in Elementary School, and it is continued by providing the instruments to the teachers as the need assessment. Furthermore, the library research is used in order to get the reference/theories about the implementation of inclusive education, field study. (2) Planning, it includesthe formulation of skills and expertise related to the problem, determinng the objectives to be achieved at each stage. (3) Developing preliminary form product.

Product Design describes the initial product of learning model by determining the sequence of product development. (4) Field test, design validation; conducting Focus Group Discussion (FGD) in order to gather feedback that can become the consideration in revising the model, (5) Product trials and (6) Revisionof the main product. This research is conducted in Padang inclusion Elementary School, with the research sample of regular teachers and special education teachers who have taught at least two year in inclusion class.

\section{RESEARCH RESULT}

Training model that is developed has produced three books, namely book 1 about the training implementation technique of inclusive education, book 2 contains about the program and plan of inclusive educationtraining, and book 3 is about the training material, which contains about: 1) the basic concept of inclusive education, 2) the guidelines for inclusive educationimplementation, 3) identification and assessment children with special need, 4) curriculum development in inclusion classes, (5) the accessibility of children with special need in inclusive education, and (6) learning in inclusive setting. In order to ensure that the training is not boring then it is equipped with the Compact Disc (CD) that contains a film about the implementation of inclusive education.

Operationally, training model has been proven to improve the competency of teachers in implementing inclusive education, it is proven by the test results of trainee before and after being given the training, there is an increase in the average, before the training given the average result of tests trainee is $57.8 \%$, which is in lesscategory, meanwhile after the training it risesup to $76.7 \%$, which is in good categories. The next evidence can also be seen from the results of questionnaires instrument from trainee about teacher's competence. Before the training, the average competence of trainees is $67.5 \%$, which is in the intermediate category, whereas after the training about the implementation of inclusive education,the average score of participants increases to $80.6 \%$, which is in the excellent category, it means that there is a significant increase on the competence of Elementary School teacher after being given the training on inclusive education.

The analysis results of questionnaires instrument about the response of trainees mention that $90.8 \%$ of participants like the training model that is applied, $87.5 \%$ of participants say that the training model can increase their interest and motivation, $23.3 \%$ of participants state that training methodcauses the participants feel sleepy and bored, it means that the training model makes the participants not feel sleepy and bored, $85.8 \%$ of participants say that the applied training methods help the teachers to understand training materials, $80.8 \%$ of participants mention thatthe offered material training in this model helps the teachers in improving competence in implementing inclusive education, $92.53 \%$ of participants state that the training material in relevant with the problems and needs of teachers, $79.1 \%$ of participants say that the given examples by resource persons are in accordance with the field, $75 \%$ of participants mention that the training time provided is enough in order to improve the competence of teachers in implementing inclusive education in schools. It means that the model of inclusive education training based on the need assessment and andragogy can improve the competence of Elementary School teachers. 
4

The study produces a model of inclusive education training that is practical and effective in improving the competence of Elementary School teachers on implementing inclusive education. Observation result, interviews, and questionnaireinstrument from the trainees mention that the training is not boring, it can increase motivation and enthusiasm of participants, because the method is variedin order to accommodate the adult learning, such as: using lectures, question and answer, reflection, discussion, watching movies, assignments and exercises. It is relevant with the opinion of Suprijanto (2008:86). The method that is needed in adult education includes: formal presentation, namely lectures, question and answer, discussion, symposium, audio visual (watching movies) and so on.Then, Atmodiwirio (1993) explains that there are four basic concepts about learning readiness in relation with andragogy education, namely: (1) the concept of self, (2) experience, (3) the learning readiness, and (4) perspectives on time and orientation to learning.

That opinion is also supported by Lunandi (1982) and Soedomo (1989) state that conducive learning atmospheres for adults are: (1) encouraging students to be active and develop talent, (2) the atmosphere of mutual respect, (3) the atmosphere of mutual trust and open to each other, (4) the atmosphere of self-discovery, (5) the nonthreatening atmosphere, (6) the atmosphere that recognizes the peculiarities of personal, (7) the atmosphere that allow the differences, mistakes and, hesitations, (8) allowingthe learners to study according to their interests, (9) allowingthe learners to recognize and assess the strengths and weaknesses of individual, groups, and communities, (10) allowing the learners to develop according with the values and norms that exist in community. Those requirements above are applied in training model by using training model that has been developed in that model, such as asking for reflection from participants after each learning materials are presented, providing reinforcement to the participants who actively give opinions and feedback and also questions in learning.

In addition to practical reason, training model has also proven effective to improve the competence of teachers in implementing inclusive education. It can be seen from the initial conditions of the teachers competence on the implementation of inclusive education provisioncan be seen from the analysis results ofquestionnaires instrument that on average of pedagogy competence and professional competence is in the poor category, while in social competence and personality competence, the teachershave high capability. After being tested on the model of training, all of its competences are in good category or there is an improvement.

Therefore, the training model of inclusive education has fulfilled the requirement to become a good model.According to Trianto, (2009: 25-26). A model is said to be effective if it meets the following requirements: (1) experts and practitioners based on their experiences mention that the model is effective, and (2) operationally, that model provides the expected result. (Jahaya, 2010).

\section{CONCLUSIONS SUGGESTIONS}

AND

Based on the results of this study, it can be concluded that training model of inclusive education can significantly improve the competence of Elementary School teachers in implementing inclusive education. That training model is also practical and not boring for adult learning. Therefore, it is recommended to:

LPMP institute, Department of Education division of PK-PLK, lecturers on PLB (special education major) and resource persons in seminars and training on inclusive education, the results of this research can provide input in implementing the education and training on inclusive education.

For further researchers, to conduct research and development

of training model on the implementation of inclusive education in a wider area and at a higher level, namely the inclusion of Junior High School and Senior High School teachers. So that the implementation of inclusive education can be held completely and thoroughly.

To the Director of PK-PLK Basic Education General Directorate of National Education Ministry of Basic Education needs to appointment special education teachers in inclusive schools, so that the implementation of inclusive education can be conducted properly and correctly.

To the lecturers in Special Education major that prepareteachers on inclusive education, these results should be used as one of the considerations in developing syllabus and SAP in course of inclusive education. 


\section{REFERENCES}

[1] Atmodiwirio, S. 1993. Manajemen training. Jakarta: Balai Pustaka

[2] Basleman, Anisah. 2011.Teori Belajar Orang Dewasa.Bandung: Remaja Rosdakarya.

[3] Budiyanto, 2005. Pengantar Pendidikan Inklusif berbasis Budaya Lokal. Jakarta: Depdiknas

[4] Borg, W.R., Gall, M.D. 2003. Educational Research: An Introduction. London: Longman, Inc.

[5] Depdiknas. 2003. Pengadaandan Pembinaan Tenaga Kependidikan: Pedoman Penyelenggaraan Pendidikan Terpadu/Inklusi. Jakarta: DirektoratPendidikanLuarBiasa

[6] Depdiknas. 2006. Program Pendidikan Khususdan Pendidikanlayanan Khusus: PedomanPenyelenggaraanPendidikanTerp adu/Inklusi. Jakarta: DirektoratPendidikanLuarBiasa

[7] Dick, W., \& Carey, L.1996. The systematic Design of instruction. (4 th.ed). New York: Harper Collinc College Publisher.

[8] Dyah. (2008). raj Pengkajian $\begin{array}{llr}\text { PendidikanInklusif } & \text { bagi Anak } \\ \text { Berkebutuhan Khusus pada Jenjang }\end{array}$ Pendidikan Dasar dan Menengah.(Online), (http://eprints.lib.ui.ac.id/11679/pengkajian -pendidikan-inklusifbagi anak/ diakses 1 Juli 2016)

[9] Ghafar dan Jahaya. 2010. Bias Pengajaran Guru dalam Pelajaran Khas dan Pelajaran Normal.Universitas Teknologi Malaysia (Online), (http;//eprints.utm.my/2236/1/7 9.pdf diakses 26 Desember 2016.

[10] Irdamurni, 2011. Kompetensi Guru tentang Penyelenggaraan Pendidikan Inklusif di Kota Padang. Laporan Penelitian. Tidak diterbitkan.

[11] Johnsen, Berit H dan miriam D. Skjorten. 2003. Pendidikan kebutuahn Khusus; Sebuah pengantar. Bandung. Unipub

[12] Knowles, Malcom S. 1970. "The Moderns Practice of Adult Education: Andragogy Versus Pedagogy". New York: Association Press.

[13] Knowles, Malcom S. 1993. "Contributions of Malcom Knowles," in The Christian Handbook on Adult Education eds. K.O.Gangel \& James C. Wilhoit. Victor Books. Pp. 91-103.

[14] Lindeman, E. C. 1926. "The Meaning of Adult Education (1989 edn.)", Norman: University of Oklahoma.
[15]Lunandi, A, G. 1987. Pendidikan Orang Dewasa. Jakarta: Gramedia

[16] Marzuki, Saleh. 2010.Pendidikan Nonformal DimensiDalam Keaksaraan Fungsional, Pelatihan, danAndragogY.Bandung: $\quad$ Remaja Rosdakarya

[17] Undang-undangNomor 20 tahun 2003 tentangSistemPendidikanNasional.

[18] Undang-undangR I Nomor 14 tahun 2005, tentang guru dan dosen

[19] Sugiono, 2011.Metode Penelitian Pendidikan. Pendekatan.Kuantitatif, Kualitatif, dan R\&D.Bandung: Alfabeta.

[20] Scott, K., et.al. 1995. Teacher attitudes toward increased ainstreaming: Implementing effective instruction for students with learning disabilities.. Journal of Learning Disabilities, 28, 87-94

[21] Shevin, Sapon-, M. 2007.Widening the Circle. The Power of Inclusive Classrooms. Beacon Press, Boston.

[22] Sugiyanto. 2003. Dasar-dasar Pendidikan Orang Dewasa (AndragogY). Malang: Lembaga Penerbitan Fakultas Pertanian Universitas Brawijaya.

[23] Stainback, William. \&Stainback, Susan. 1990. Support Networks for Inclusive Schooling:Independent Integrated Education. Baltimore: Paul H. Brooks.

[24] Soenarno, Dkk. 2008. The Dinamics of Human Recources Becoming A True HRSpecialist. Jakarta: Grasindo

[25] O’Neil, J. 1995. Can Inclusive Work? A Conversation With James Kauffman and Mara Sapon-Sevin.Educational Leadership 52(4)7-11.

[26]Permendiknas RI Nomor 70 tahun 2009 tentangPendidikanInklusifBagiPesertadidik yang

MemilikiKelainandanMemilikiPotensiKece rdasandan/atauBakat Istimewa

[27] Peraturan Pemerintah nomor 19 tahun 2005, tentang kompetensi

[28] Whitten, Jeffrey L., Lonnie D. Bentley, dan Kevin C. Dittman, 2004. Systems Analysis and Design Methods,Boston: McGraw Hil 